\title{
Impact of HIV/AIDS on the Psychosocial Development of Children
}

\author{
Laveena D’Mello ${ }^{1}$, Meena monteiro ${ }^{2}$, Sathyendra Prakash ${ }^{3}$ \\ ${ }^{1}$ Assistant Professor, Social Work Department, Srinivas Institute of Management Studies, \\ Mangalore, Karnataka, INDIA \\ ${ }^{2}$ Associate Professor, MSW Department, School of Social Work, Roshni Nilaya, Mangalore, \\ Karnataka, INDIA \\ ${ }^{3}$ Social Worker, Shanthi Sadan, University Road, Thokkottu, Mangalore, Karnataka, INDIA. \\ E-mail: lavynoronha@gmail.com
}

Type of the Paper: Medical Case Study.

Type of Review: Peer Reviewed.

Indexed In: OpenAIRE.

DOI: http://dx.doi.org/10.5281/zenodo.833489.

Google Scholar Citation: IJHSP

\section{How to Cite this Paper:}

D’Mello, Laveena., monteiro, Meena., Prakash, Sathyendra. (2017). Impact of HIV/AIDS on the Psychosocial Development of Children. International Journal of Health Sciences and Pharmacy (IJHSP), 1(2), 5-10.

DOI: http://dx.doi.org/10.5281/zenodo.833489.

International Journal of Health Sciences and Pharmacy (IJHSP)

A Refereed International Journal

(C) With Authors.

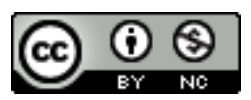

This work is licensed under a Creative Commons Attribution-Non Commercial 4.0 International License subject to proper citation to the publication source of the work.

Disclaimer: The scholarly papers as reviewed and published by the Srinivas Publications (S.P.), India are the views and opinions of their respective authors and are not the views or opinions of the SP. The SP disclaims of any harm or loss caused due to the published content to any party. 


\title{
Impact of HIV/AIDS on the Psychosocial Development of Children
}

\author{
Laveena D’Mello ${ }^{1}$, Meena monteiro ${ }^{2}$, Sathyendra Prakash ${ }^{3}$ \\ ${ }^{1}$ Assistant Professor, Social Work Department, Srinivas Institute of Management Studies, \\ Mangalore, Karnataka, INDIA \\ ${ }^{2}$ Associate Professor, MSW Department, School of Social Work, Roshni Nilaya, Mangalore, \\ Karnataka, INDIA \\ ${ }^{3}$ Social Worker, Shanthi Sadan, University Road, Thokkottu, Mangalore, Karnataka, INDIA. \\ E-mail: lavynoronha@gmail.com
}

\begin{abstract}
Acquired Immune Deficiency Syndrome (AIDS) is the leading cause of death in children under age five, in many parts of Africa and South East Asia. The interval between exposure to Human Immunodeficiency Virus (HIV) and the development of AIDS is shorter in children than in adults. Infants infected with HIV have a high chance of developing AIDS within one year and dying before age three. In the remainder, AIDS progresses more slowly; the average child patient survives to adolescence. In the past, the world has faced many pandemics like cholera and plague. At the turn of the 20th century, the world faced influenza pandemic [1]. Every fifty to sixty years, the world has faced a new disease that has been of the nature of an epidemic. These diseases have left a trail of death and morbidity. There has been widespread fear and stigma attached to the victims due to ignorance and fear. As the diseases have progressed people have made efforts to study the issues. They have found the cause, spread, cures, and vaccines to prevent the spread of the disease. The aim of the study is to know the Impact of HIV/AIDS on the Psychosocial Development of Children and the objectives are to study the knowledge and awareness about HIV/AIDS. And to study the psychosocial problems faced by the children. In this regard, the researcher conducted a survey of 50 samples of children below the age group of 18 from the community.
\end{abstract}

Keywords: HIV/AIDS, HIV Positive children, Disease, counseling, stigma and psychological problems.

\section{INTRODUCTION :}

HIV/AIDS has entered every part of the world, posing a threat to people from all walks of life. In this unit, we have discussed the global scenario of HIV/AIDS. We have also tried to get a picture of the problem in different regions of the world and the associated social development problems in different countries. It is evident that no country in the world can deny the prevalence of HIV/AIDS and if it denies, it affirms the fact that there is no proper surveillance system there. The HIV/AIDS epidemic is going to be more terrible to live through than any of us can imagine. We are only beginning to experience the effects of AIDS deaths. The most important interventions for children are nationally oriented responses that identify, target and effectively implement mechanisms to provide economic and other assistance to poor families and to maintain and improve their access to services. In this way, the values and organizing coherence of families, neighborhoods, and schools will assist children to cope with the increasing adversity accompanying the epidemic. Human Immunodeficiency Virus (HIV) is a virus that aggressively attacks the immune system. Part of the reason HIV is such a serious virus is that attacks and destroys cells of the immune 
system, called T-cells or CD4 cells that are designed to fight infections and diseases [2]. Acquired Immune Deficiency Syndrome (AIDS) is a condition caused by HIV. AIDS occurs when an individual is experiencing more than one chronic opportunistic infection, which results from the destruction of the body's defense by the Human Immunodeficiency Virus.

\section{AIDS IN CHILDREN :}

With 27 million pregnancies a year and an overall estimated $0.3 \%$ prevalence rate of HIV infection among pregnant women, it is estimated that about 1,00,000 HIV-infected women deliver every year. Using a conservative vertical transmission rate of $30 \%$, about 30,000 infants acquire HIV infection every year. The life span of a child infected by HIV infection is lower than that found in adults. Thus HIV infection may increase healthcare expenditure both public and at the family level. Increasing number of children infected by HIV has a propensity to alter the mortality rates in childhood [3, 4]. The effects of the epidemic among young children are serious and far-reaching; AIDS threatens to reverse years of steady progress in child survival, and has already doubled infant mortality in the worst affected countries.

In India, the high HIV prevalence States coincide with those states that are doing better in terms of health indicators and development, in general. The less developed and more populated states, in the north and the central, part of the country are so far classified as "low HIV prevalence States". These States reveal a variety of vulnerability factors which can fuel the spread of HIV epidemic such as wide socio-economic inequity leading 1 to high degree migration particularly towards metropolitan cities where HIV prevalence is high among "at risk" individuals, inadequate 1 infrastructure in health and social services, illiteracy, low women empowerment, low school enrollment limited, access to information etc, the degree of success in programmatic response by these states would determine the spread of HIV and its impact on health indicators including development in the near future $[5,6]$. Although currently, India has overall low "prevalence of HIV among pregnant women in many parts of the country, with the progression of the epidemic in general population it is bound to rise in women in reproductive age group and thereby increasing chances of MTCT of HIV infection. Therefore the challenge for future is how to keep the prevalence of HIV infection among women low and reduce mother to child transmission. HIV can be transmitted from mother to child in three ways. It can occur in the womb, at the time of delivery and also when the child is breast- fed. Womb Throughout the period of pregnancy, mother is capable of infecting the fetus. Fetus receives nutrition from the mother through the placenta (before birth). When the mother has a high viral concentration in the blood, some of the virus can pass from the mother to the fetus through the placenta. It is seen throughout the period of pregnancy. A small number of fetuses get infected through this route, At the Time of Birth: The lining of the birth canal (vagina) contains a high concentration of HIV. The baby may sustain minor cuts in the mucus membrane and in the skin during the process of birth. Hence, the baby can get infected. It has been also shown that the maximum chance of infection of the fetus occurs during the time of delivery. About 30 per cent to 40 per cent of children born to HIV mothers become infected at the time of delivery. Breast Milk: About 14 percent of children who are breastfed by the HIVinfected mothers will contract the infection. Hence, practices which change breast- feeding reduce HIV transmission. The difference in risk between developing and developed countries is largely due to feeding practices: breastfeeding is more common and is usually practiced for a longer period in developing countries than in the industrialized or developing world. It is estimated that a child born uninfected to an HIV-positive mother has a one in five chance of acquiring the virus from her milk if it is breastfed. In places where breastfeeding is the norm, this route may account for, more than one-third of mother- tochild transmission. Mother-to-Child transmission occurs at three stages. These stages are in the womb, at the time of birth and through breastfeeding [7-9]. We discussed also how these transmissions occur at various stages. In this unit, we also analyzed the rates of mother-to-child transmission of HIV under the different circumstances. There are various 
issues related to mother-to-child transmission, which is still debatable. Some of the debatable issues is: whether HIV positive women should be encouraged to have a child' or not: if alternative feeding is available; whether each and every woman and man should undergo HIV counselling and testing or not; and whether HIV positive men and women should marry amongst themselves or not etc. at the end of the unit some of the preventive strategies were discussed very briefly.

\section{DIAGNOSIS IN CHILDREN :}

Infants can be diagnosed by direct culture of the HIV virus, PCR testing, and p24 antigen testing. By one month of age, results are highly accurate. Diagnostic blood testing in children older than 18 months is similar to adult testing. Children with AIDS are more likely to develop bacterial infections, inflammation of the lungs, and AIDS-related brain disorders than are HIV-positive adults.

\section{PSYCHOSOCIAL IMPACT :}

Affected and orphaned children are often traumatized and suffer a variety of psychological reactions to parental illness and death. They endure exhaustion and stress from work and worry, as well as insecurity and stigmatization as it is either assumed that they too are infected with HIV or that their family has been disgraced by the virus. Loss of home, dropping out of school, separation from siblings and friends, increased workload and social isolation may all impact negatively on current and future mental health. Existing studies of children's reactions suggest that they tend to show internalizing rather than externalizing symptoms in response to such impacts-depression, anxiety and withdrawal as opposed to aggression and other forms of antisocial behavior.

\section{RESULTS AND DISCUSSION :}

Knowledge and Awareness: The respondents of this study are male $52 \%$ belong to the age group between $12-14$ and $48 \%$ of females belong to 12 to 18 years. This age is important in the child's physical, mental development process. The study revealed that all the respondents would like to continue the education with the support from parents and from relatives. The respondents are from Standard 4th to PUC. Even though they are infected, they enjoy the school hours and activities. Most of them are from rural area engage in coolie and their income is between Rs. 20,000/- and Rs.40, 000 /- annually.

The respondent's shared their knowledge about HIV/AIDS. $76 \%$ of the respondents have gained knowledge from posters and through counseling. Whereas only $20 \%$ are do not know about HIV/AIDS. Only 4\% of them respondents are aware to some extent. 64\% of the children shared that AIDS can be treated or controlled through the medicine and remaining $36 \%$ of the children ignored it. $54 \%$ of the respondents came to know their HIV status due to Regular visits to the hospital for the CD4 test. The counseling before the test helps to internalize the cause as well as the status of the individual. $50 \%$ of the respondents are getting Medical and financial benefits which are indeed a great help for them. Respondents are enthusiastic in the academic field and attending the classes regularly. $64 \%$ of them shared their school activities. They are accepted in the school and society. All the respondents were encouraged by their parents and their friends to attend the school.

Psychological Problems: The psychological problems or the stress is common to all. But in HIV the Psychological problems are much more common and savior to the respondents. The first detection and knowing the status; $82 \%$ of the respondents were ignored about the status because; the blood test was done when they were very young. $16 \%$ of the children shared when they heard the status first time they felt very sad and 2\% were confused. And regarding the motivation by parents and the guardians to test; $60 \%$ of the respondents were motivated by the parents for their HIV blood test. During the time they were unaware, the test was done. All the respondents shared their health condition is normal at present and no major health issues.

The awareness given to parents and for caretakers made the children are healthy, counselors too gave the knowledge to take care of children's health. The psychological problems faced by the children easily coped up with parental support. The single parents and the family members of the $82 \%$ respondents supported to overcome the anxiety. There were stigma-free homes. All the respondents expressed that there is no stigma \& 
discrimination at home. $72 \%$ of the children used to share their feelings with their friends. Majority of the respondent's parents are concerned with the personal matters of the respondents. So this attitude definitely made difference in the attitude and behavior to reduce the stigma and discrimination in the society. The $56 \%$ respondent's family has a good relationship with relatives and neighbors.

\section{FINDINGS :}

Based on the above analysis, the findings can be attributed to the following reasons: More than half of the respondent's shared knowledge and awareness about HIV/AIDS. The $76 \%$ of the respondents have developed their knowledge through communication materials and through counseling. Since these children are on ART they understood that HIV/AIDS is controlled or treated by the medicines. If anyone gets HIV/AIDS they will fall ill. Counseling helps to understand their status and cope up the feelings. Regular visits to the hospital and the counseling increases the knowledge with children which help to internalize the condition. The children do not stay with parents but with the relatives. No discrimination found at home with the children and treated positive and negative children equally. Active Participation in the school activities helped to minimize the stigma in the society. Children are interested in going to school and enjoying the school activities like nor hours.

\section{SUGGESTIONS :}

The majority of the respondents would like to go to school. It is necessary to provide knowledge on HIV/AIDS to School teachers. The majority of the respondents do not know about their HIV status. Some of them know during the CD4 test. If the parents take responsibility to explain the children it is much better to make them understand the situation and its impact. NGO's working with HIV/AIDS should motivate the parents to reveal the children's status. The school should play a major role in minimizing the stigma \& discrimination so that the adults will get motivated to it. The District HIV positive Network should motivate the people to disclose their HIV status and should create awareness [13-15].

\section{CONCLUSION :}

HIV positive children are interested in their studies and they are regular in the school and actively participate in the school activities. The parents and the teachers support, motivate them to study further which allows sharing personal feelings with their friends and parents. The researcher found that in this study if the school should play a major role to provide accurate knowledge on HIV/AIDS to the children and their rights. It is necessary that every child should know their rights. NGO's and CBO's play a major role in taking responsibility for creating the better tomorrow.

\section{REFERENCES :}

[1] United Nations Development Programme (UNDP) (2006), Human Development Report 1994. New York: Oxford University Press.

[2] Nath .L.M, (1998). The Epidemic in India. An Overview, In Godwin P(ed) The Looming Epidemic; The impact of HIV and AIDS in India”, Mosiac Book, New Delhi

[3] Scott G.B., Hutto c., Makuch R.W., Mastrucci M.T.,et.l (1989). Survival in children with perinatally acquired human immunodeficiency virus type 1 infection. The New England Journal of Medicine, U.S. 321(26):1791-1796,DOI:10.1056/ NEJM198912283212604.

[4] Akeroyd A.V. (1997). Socio cultural aspects of AIDS in Africa: Occupational and gender issues. AIDS in Africa and the Caribbean. Boulder, CO: West view Press, 11-32

[5] Sebi Das, Aparna Mukherjee, Rakesh Lodha and Manju Vatsa (2010). Quality of Life and Psychosocial Functioning of HIV Infected Children. Indian Journal of Paediatrics, New Delhi, India, Vol 77, 633.

[6] Bandarage A.(1984). Women in development: Liberalism, Marxism and Marxist feminism. Development and Change 15: 495-515.

[7] Carlton-Ford S. (2005). The impact of war, adult HIV/AIDS, and militarization on young children's mortality. 
Sociological Studies of Children and Youth 10: 231-255.

[8] Doctor H.(2004). Parental survival, living arrangements, and school enrolment of children in Malawi in the era of HIV/AIDS. Journal of Social Development in Africa 19: 31-56.

[9] Lauchman P., Poblete X., Ebigbo PO, Nyandiya-Bundy S., Bundy RP, Killian B., and Doek J. (2002) Challenges facing child protection: The influence of HIV and AIDS on child protection. Child Abuse \& Neglect 26: 587-617.

[10] Safman R.M. (2004). Assessing the impact of orphanhood on Thai children affected by AIDS and their caregivers. AIDS Care 16: 11-19.

[11] Nagendra Shilaja, (2008). Aids in India. ABD Publication, Jaipur, India.

[12] Nagla Madhu (2014).Sociology of Health- Reading in Indian Society. Sage Publication, USA.

[13] D’Mello Laveena. B. M. Govindaraju, Monteiro Meena (2016). A Study On The Challenges of HIV Positive Children in Dakshina Kannada, International Journal of Advanced Trends in Engineering and Technology (IJATET), 1(1), 42-48.

[14] D’Mello Laveena, B. M. Govindaraju (January 2016). A Study on Stigma Management among HIV positive people. International Journal of Management, 6(1), 442-452.

[15] D’Mello Laveena and B. M. Govindraju (2017). A study on SocioEconomic Condition of HIV Positive People in Dakshina Kannada. International Journal of Health Sciences and Pharmacy (IJHSP), 1(1), DOI: http://dx.doi.org /10.5281/zenodo.579647, 12-20. 